\title{
Elucidation of stability profiles of common chemistry analytes in serum stored at six graded temperatures
}

https://doi.org/10.1515/cclm-2018-1109

Received October 14, 2018; accepted January 31, 2019; previously published online March 12, 2019

\section{Abstract}

Background: Many reports address the stability of biochemical analytes in serum. However, studies covering a wide range of storage temperatures are unavailable. Using equipment enabling precise temperature control, we investigated the effect of six different storage temperatures on serum analytes.

Methods: Serum specimens from seven healthy volunteers were obtained and divided into multiple aliquots for storage at $-30,-20,-10,0,4$, and $25^{\circ} \mathrm{C}$. On days $1,3,7,14$, 28 and 56, the aliquots stored at each temperature were relocated to a deep freezer maintained at $-80{ }^{\circ} \mathrm{C}$. On day 60 , all aliquots were measured collectively for 13 major chemistry analytes.

Results: (1) At $25^{\circ} \mathrm{C}$, alanine aminotransferase (ALT), creatine kinase (CK), aspartate aminotransferase (AST) and total bilirubin (TBil) were very unstable especially on day 7 and later. (2) At $\leq 4{ }^{\circ} \mathrm{C}$, alkaline phosphatase (ALP), $\gamma$-glutamyltransferase (GGT), amylase (AMY), highdensity lipoprotein-cholesterol (HDL-C), low-density lipoprotein-cholesterol (LDL-C), triglyceride (TG), TBil and complement component-4 (C4) were generally stable and were very stable at $25{ }^{\circ} \mathrm{C}$ until day 14. (3) Between -20 and $4{ }^{\circ} \mathrm{C}$, especially at $-10{ }^{\circ} \mathrm{C}$, test results of ALT, AST and lactate dehydrogenase (LDH) showed prominent decreases, but their stability was greatly improved at $-30{ }^{\circ} \mathrm{C}$. (4) In contrast, the value of complement component-3 (C3) increased at $\geq-20^{\circ} \mathrm{C}$. (5) At $-30^{\circ} \mathrm{C}$, test results of all analytes were generally very stable except for ALT and $\mathrm{CK}$, which showed noticeable reductions in activity after 14 days.

\footnotetext{
*Corresponding author: Kiyoshi Ichihara, MD, PhD, Department of Clinical Laboratory Sciences, Faculty of Health Sciences, Yamaguchi University Graduate School of Medicine, Minami-Kogushi 1-1-1, Ube 755-8505, Japan, Phone: +81-90-7895-0432, Fax: +81-836-35-5213, E-mail: ichihara@yamaguchi-u.ac.jp Yoshihisa Shimizu: Department of Medical Life Science, Faculty of Medical Bioscience, Kyushu University of Health and Welfare, Nobeoka, Japan
}

Conclusions: This is the first study to assess the stability of serum analytes at six graded temperatures simultaneously. Each analyte has a unique stability pattern for a range of temperatures.

Keywords: bilirubin; complement C3; complement C4; deep freeze; enzymes; HDL-cholesterol; LDL-cholesterol; stability; triglyceride.

\section{Introduction}

There have been many studies on the effects of specimen storage at various temperatures on laboratory test results. Short-term stability of human serum specimens stored in a refrigerator (at $4^{\circ} \mathrm{C}$ ) and/or at room temperature (RT) have been compared for common biochemical analytes [1-4]. Most reports showed variable degrees of instability of the test results for lactate dehydrogenase (LDH), alanine aminotransferase (ALT), and complement component-3 (C3) at $4^{\circ} \mathrm{C}$ and RT, but the results for creatine kinase (CK) and alkaline phosphatase (ALP) have been mixed, especially at RT.

Longer-term stability of human specimens has been examined for storage at $-20{ }^{\circ} \mathrm{C}[5-9],-25{ }^{\circ} \mathrm{C}$ [10], and $-30{ }^{\circ} \mathrm{C}$ [11] in comparison to $4^{\circ} \mathrm{C}$ and/or RT. Most reports showed a gradual decrease of LDH, ALT, CK, and an increase of the $\mathrm{C} 3$ test results in the frozen states over a period of 28-90 days. Some inconsistencies in the results among these reports appear to be attributable to differences in the storage period and target temperature set by each investigator.

Despite efforts to keep biobanked material at a stable temperature, accidental or inadvertent fluctuations of storage temperature, especially at or near the freezing range $\left(0\right.$ to $\left.-30{ }^{\circ} \mathrm{C}\right)$, may occur. As previous studies have only covered a single temperature in the range, we aimed to determine the stability of serum analytes from freshly drawn blood samples at six graded temperatures simultaneously: $-30{ }^{\circ} \mathrm{C}$ and $-20{ }^{\circ} \mathrm{C}$ (freezing temperatures), $-10{ }^{\circ} \mathrm{C}$ (semi-freezing temperature), $0{ }^{\circ} \mathrm{C}$ and $4{ }^{\circ} \mathrm{C}$ (nearfreezing temperature), and $25^{\circ} \mathrm{C}(\mathrm{RT})$. The target tests we chose were 13 major clinical chemistry analytes whose 
molecular stability during storage for future re-testing is generally viewed with some concern. The time periods of serum storage examined ranged from 0 to 56 days.

\section{Materials and methods}

\section{Preparation of serum specimens and conditions for storage}

We obtained approximately $150 \mathrm{~mL}$ of blood from each of seven healthy volunteers aged 20 to 65 years old. The blood was drawn four times in increments of 40, 40, 40 and $30 \mathrm{~mL}$ through a butterfly needle into a $50 \mathrm{~mL}$ disposable syringe, and each portion was poured into a conical centrifuge tube (Corning Inc., USA). After centrifugation at $1200 \times \mathrm{g}$ for $10 \mathrm{~min}$, pooled serum from each individual was divided into 38 aliquots. Each aliquot was assigned a specified storage temperature (one from $-30,-20,-10,0,4$ and $25^{\circ} \mathrm{C}$ ) and storage duration (one from 1, 3, 7, 14, 28 and 56 days). Therefore, a total of $6 \times 6$ aliquots were allocated to cover all conditions. Two more aliquots (for duplicate measurement) were allocated for storage at $-80{ }^{\circ} \mathrm{C}$ for a fixed duration of 60 days for determination of base value (see below for the concept of collective measurement). The total number of aliquots was 266 (seven individuals $\times 38$ ). For storage containers, we used $1.2 \mathrm{~mL}$ CryoTubes with an outer cap (Nunc: Thermo Fisher Scientific, USA).

\section{Temperature-controlled storage equipment}

For storage at $-80^{\circ} \mathrm{C}$, we used a VT-208 deep freezer (Nihon Freezer Co., Japan). For storage at $-30,-10$, and $0{ }^{\circ} \mathrm{C}$, we used a portable incubator box capable of precise temperature control (Cryo Porter ${ }^{\mathrm{TM}}$ CS-80CP; Scinics Corp., Tokyo, Japan). This box can maintain a specified preset temperature over a range of -80 to $50{ }^{\circ} \mathrm{C}$ with a precision of $\pm 0.2^{\circ} \mathrm{C}$ when it is housed in a space at RT. For storage at $25^{\circ} \mathrm{C}$, we used an incubator box (MIR-154-PJ; Panasonic Healthcare Co., Tokyo, Japan) also capable of precise temperature control. All of these temperature-controlled storage devices possess a visual display with beep functions for current temperature and alarm status to allow for external monitoring. For storage at $-20^{\circ} \mathrm{C}$ and $4{ }^{\circ} \mathrm{C}$, we used a highgrade freezer/refrigerator (SJ-23TM; Sharp Corp., Japan), for which we confirmed the stability of the temperature within a precision of $\pm 0.5^{\circ} \mathrm{C}$ (SD) as specified by the manufacturer, by external monitoring using a PC-3300 digital thermometer (Sato Keiryoki Mfg. Co., Tokyo, Japan).

\section{Target analytes and measurements}

After the assigned duration of storage (1, 3, 7, 14, 28 or 56 days) at a given temperature was completed, each aliquot was relocated to the deep freezer for storage at $-80{ }^{\circ} \mathrm{C}$ until the time of collective measurement on day 60 . Therefore, the length of storage at $-80{ }^{\circ} \mathrm{C}$ was 60 days - (days of storage at a given temperature). For example, if an aliquot was assigned for storage at $4{ }^{\circ} \mathrm{C}$ for 14 days, then it was stored for another $60-14=46$ days at $-80^{\circ} \mathrm{C}$. This scheme of collective measurement was essential to eliminate any influence of between-day assay variations in the analysis of storage stability.
On day 60, all specimens were thawed in batches by placing a rack of sample containers into a $37^{\circ} \mathrm{C}$ water bath for $10 \mathrm{~min}$ for collective measurements of the following 13 biochemistry analytes using a Beckman Coulter AU480 analyzer: ALT, aspartate aminotransferase (AST), ALP, LDH, $\gamma$-glutamyltransferase (GGT), amylase (AMY), CK, triglyceride (TG), high-density lipoprotein-cholesterol (HDL-C), lowdensity lipoprotein-cholesterol (LDL-C), total bilirubin (TBil), C3 and complement component-4 (C4). The assay methods and analytical precision for all 13 analytes are listed in Table 1. Internal quality control was performed by daily measurement of three levels of quality control (QC) sera provided for the AU480 analyzer. The within- and between-day coefficients of variation (CVs) listed in the table were based on the results for QC specimens near the normal levels.

\section{Data analyses}

We assumed that all of the analytes were stable when stored in the deep freezer (at $-80^{\circ} \mathrm{C}$ ) (see the Discussion for the validity of this assumption). Therefore, test results of the specimens stored continuously at $-80{ }^{\circ} \mathrm{C}$ until day 60 (the time of collective measurements) were regarded as the values at day 0 . The time-dependent alterations in values of the aliquots stored at the other temperatures are expressed as percent change $(\% \Delta)$ from the values at day 0 . For testing of the differences in values on each day from those on day 0 , Wilcoxon signed rank test was performed with Bonferroni correction for the multiplicity of testings [12] applied per analyte per storage temperature: i.e., each P value was multiplied by 6 (the number of storage durations). For evaluation of the practical significance of $\% \Delta$, we referred to the $\mathrm{CV}_{\mathrm{I}}$ or within-individual $\mathrm{CV}$ posted on Westgard's web site (https://www.westgard.com/biodatabase1.htm). We regard $0.5 \times \mathrm{CV}_{\mathrm{I}}$, which corresponds to the so-called allowable limit of error, as a guide value for interpreting the magnitude of the observed $\% \Delta$.

The analyses and graphical presentation of the results were created by use of StatFlex Ver 6.0 (Artech, Co., Osaka, Japan).

\section{Ethical considerations}

This study was approved by the Ethical Committee of Yamaguchi University Graduate School of Medical Sciences for Faculty of Health Sciences in June 2015 (No. 199-2015). Informed consent for the provision of blood samples was obtained from each volunteer.

\section{Results}

Serial changes in the test results over time for the 2-month period at each of the six storage temperatures are shown in Figure 1 for six selected analytes: ALT, LDH, CK, HDL-C, LDL-C and $\mathrm{C} 3$. The averages of $\% \Delta$ in the measured values among the seven individuals for days 14, 28, and 56 are shown at the top of each panel. The major findings were as follows:

1. ALT showed the most prominent time-dependent decrease in test results at $25^{\circ} \mathrm{C}$, then at $-10{ }^{\circ} \mathrm{C}$, followed by $-20^{\circ} \mathrm{C}$ and $-30{ }^{\circ} \mathrm{C}$. It is notable that ALT activity was rather stable at $4^{\circ} \mathrm{C}$ until day 14 . 
Table 1: List of assay methods and imprecision near the mid-normal ranges.

\begin{tabular}{|c|c|c|c|c|c|c|c|}
\hline Abbrev & Analytes & Method & Reagent & Traceability & $\begin{array}{l}\text { Mean of QC } \\
\text { specimen }\end{array}$ & $\begin{array}{r}\text { Within-day } \\
\text { CV }\end{array}$ & $\begin{array}{r}\text { Between-day } \\
\text { CV }\end{array}$ \\
\hline AST & $\begin{array}{l}\text { Aspartate } \\
\text { aminotransferase }\end{array}$ & $\begin{array}{l}\text { JSCC method (no addition } \\
\text { of pyridoxal phosphate) }\end{array}$ & Beckman Coulter & $\begin{array}{l}\text { JCCLS } \\
\text { CRM-001b }\end{array}$ & $43.4 \mathrm{U} / \mathrm{L}$ & 2.39 & 0.89 \\
\hline ALT & $\begin{array}{l}\text { Alanine } \\
\text { aminotransferase }\end{array}$ & $\begin{array}{l}\text { JSCC method (no addition } \\
\text { of pyridoxal phosphate) }\end{array}$ & Beckman Coulter & $\begin{array}{l}\text { JCCLS } \\
\text { CRM-001b }\end{array}$ & $44.3 \mathrm{U} / \mathrm{L}$ & 1.11 & 0.61 \\
\hline LDH & $\begin{array}{l}\text { Lactate } \\
\text { dehydrogenase }\end{array}$ & $\begin{array}{l}\text { JSCC method (lactate to } \\
\text { pyruvate, OD amplified) }\end{array}$ & Beckman Coulter & $\begin{array}{l}\text { JCCLS } \\
\text { CRM-001b }\end{array}$ & $253 \mathrm{U} / \mathrm{L}$ & 1.39 & 4.99 \\
\hline ALP & $\begin{array}{l}\text { Alkaline } \\
\text { phosphatase }\end{array}$ & $\begin{array}{l}\text { JSCC method (kinetic rate } \\
\text { method (using AMP buffer) }\end{array}$ & Beckman Coulter & $\begin{array}{l}\text { JCCLS } \\
\text { CRM-001b }\end{array}$ & $155.9 \mathrm{U} / \mathrm{L}$ & 0.77 & 3.02 \\
\hline GGT & $\begin{array}{l}\text { Gamma-glutamyl } \\
\text { transferase }\end{array}$ & $\begin{array}{l}\text { JSCC method } \\
\text { (GluCANA) }\end{array}$ & Beckman Coulter & $\begin{array}{l}\text { JCCLS } \\
\text { CRM-001b }\end{array}$ & $59.2 \mathrm{U} / \mathrm{L}$ & 1.57 & 3.04 \\
\hline CK & Creatine kinase & JSCC method & Beckman Coulter & JCCLS CRM-001b & $92.3 \mathrm{U} / \mathrm{L}$ & 0.88 & 2.23 \\
\hline AMY & Amylase & $\begin{array}{l}\text { JSCC method (substrate: } \\
\text { ethylidene-G7-PNP) }\end{array}$ & Beckman Coulter & $\begin{array}{l}\text { JCCLS } \\
\text { CRM-001b }\end{array}$ & $156.2 \mathrm{U} / \mathrm{L}$ & 1.01 & 0.00 \\
\hline TG & Triglyceride & $\begin{array}{l}\text { Timed endpoint enzyme } \\
\text { colorimetry (glycerol- } \\
\text { removed) }\end{array}$ & Beckman Coulter & JCCRM 223,224 & $1.61 \mathrm{mmol} / \mathrm{L}$ & 0.64 & 0.70 \\
\hline HDL-C & HDL-cholesterol & $\begin{array}{l}\text { Timed endpoint direct } \\
\text { method }\end{array}$ & Beckman Coulter & $\begin{array}{l}\text { JCCRM } \\
223,224\end{array}$ & $1.40 \mathrm{mmol} / \mathrm{L}$ & 1.00 & 1.21 \\
\hline LDL-C & LDL-cholesterol & $\begin{array}{l}\text { Timed endpoint direct } \\
\text { method }\end{array}$ & Beckman Coulter & $\begin{array}{l}\text { JCCRM } \\
224\end{array}$ & $1.56 \mathrm{mmol} / \mathrm{L}$ & 1.08 & 2.55 \\
\hline TBil & Total bilirubin & Enzymatic method & Beckman Coulter & $\begin{array}{l}\text { NIST } \\
\text { SRM916 }\end{array}$ & $23.4 \mu \mathrm{mol} / \mathrm{L}$ & 0.93 & 0.44 \\
\hline C3 & $\begin{array}{l}\text { Complement } \\
\text { Component } 3\end{array}$ & Turbidimetric method & Beckman Coulter & CRM470 & $0.92 \mathrm{~g} / \mathrm{L}$ & 2.56 & 1.98 \\
\hline $\mathrm{C} 4$ & $\begin{array}{l}\text { Complement } \\
\text { Component } 4\end{array}$ & Turbidimetric method & Beckman Coulter & CRM470 & $0.17 \mathrm{~g} / \mathrm{L}$ & 1.72 & 1.40 \\
\hline
\end{tabular}

CV, coefficient of variability; HDL-C, high-density lipoprotein-cholesterol; LDL-C, low-density lipoprotein- cholesterol; JSCC, Japan Society of Clinical Chemistry; OD, optical density. Between-day CVs are net values subtracted of within-day component of variations.

2. LDH activity showed a prominent reduction at $-10,0$, and $4{ }^{\circ} \mathrm{C}$ in that order of magnitude. In contrast, the activity was relatively stable at $-30{ }^{\circ} \mathrm{C}$ and at $25{ }^{\circ} \mathrm{C}$ until day 14.

3. Interestingly, $\mathrm{CK}$ activity was more stable at $-10,0$, and $4{ }^{\circ} \mathrm{C}$ than at -30 or $-20^{\circ} \mathrm{C}$, in sharp contrast to that of ALT or LDH. However, its activity rapidly decreased when stored at $25^{\circ} \mathrm{C}$ for more than 7 days.

4. Test results of TG were notably stable if it was stored at $0{ }^{\circ} \mathrm{C}$ or below for the entire 2-month period. A tendency for the values to decrease slightly was noted at 4 and $25^{\circ} \mathrm{C}$ after 7 days.

5. Test results of HDL-C were very stable during storage at all of the low-temperature zones between $-30{ }^{\circ} \mathrm{C}$ and $4{ }^{\circ} \mathrm{C}$. However, at $25^{\circ} \mathrm{C}$, HDL-C notably showed a biphasic pattern of a slight increase by $9 \%$ on day 3 with subsequent slight decrease after storage for longer than 14 days.

6. In sharp contrast to the other analytes, C3 showed a storage-dependent increase in values at all temperatures and especially above $-10{ }^{\circ} \mathrm{C}$. The increase in $\mathrm{C} 3$ values occurred more rapidly at $25^{\circ} \mathrm{C}$ even on day 3 .
The serial changes over time for all of the other analytes are shown in Supplementary Figure 1.

Figure 2 provides a summary of the serial changes in values over time at each storage temperature, which are shown in Supplementary Figure 1. The average $\% \Delta$ in value on each day from that at day 0 is represented by a colored bar in each cell. The level of statistical significance for each change is expressed by three different grades: $\mathrm{p}<0.05$ by bold font, $\mathrm{p}<0.01$ by light gray background, and $\mathrm{p}<0.001$ by gray background in each cell.

Overall, we obtained the following findings:

1. At $-30{ }^{\circ} \mathrm{C}$, all 13 analytes were generally very stable although ALT and CK showed minor reductions in their activities after storage of longer than 14 days.

2. At $25{ }^{\circ} \mathrm{C}, \mathrm{ALT}, \mathrm{CK}, \mathrm{AST}$, and TBil were very unstable especially after day 7.

3. The values of ALP, GGT, AMY, HDL-C, LDL-C, TG, and TBil were generally very stable when these analytes were stored at $4{ }^{\circ} \mathrm{C}$ or below. They were also stable at $25{ }^{\circ} \mathrm{C}$ for $7-14$ days except for TBil, which showed a tendency to rapidly decrease in value even by day 3 . 
4. ALT, AST, and LDH showed a prominent decrease in test results at -20 to $4{ }^{\circ} \mathrm{C}$ and especially at $-10{ }^{\circ} \mathrm{C}$.

5. $\mathrm{C} 3$ showed a time-dependent gradual increase in values at temperatures above $-20{ }^{\circ} \mathrm{C}$. $\mathrm{C} 4$ also showed a similar pattern of increase although to a much lesser degree.

\section{Discussion}

\section{Experimental design}

There have been a host of reports on the storage stability of bioactive substances in serum. Even when limiting the reports to those dealing just with the biochemical analytes evaluated in the present study, there are still a number of them [1, 2, 4, 5, 11, 13-15]. However, after carefully assessing their results, we noted large between-day fluctuations of values or non-monotonous/inconsistent time courses of the changes $[16,17]$. Such a tendency was noted especially in those reports published in the 1970s or earlier. Therefore, in this discussion, we limited our consideration to those studies that were relevant to our experimental conditions and were conducted with well-controlled measurements after the 1980s.

Almost all of the previous reports examined storage stability under two or three conditions, i.e. $-20{ }^{\circ} \mathrm{C}$ and $4{ }^{\circ} \mathrm{C}$ and/or RT. Because we sometimes experience accidental or inadvertent fluctuations of storage temperature, we thought it necessary to analyze a wider range of temperatures and determine the degree of latitude allowable in the temperature settings. The present study is the first report, to the best of our knowledge, to investigate six different temperatures in parallel for storage stability of 13 major chemistry analytes whose molecular stability during storage for future re-testing is generally viewed with some concern. For storage at $-30,-10$ and $0{ }^{\circ} \mathrm{C}$, we used a portable incubator box that is capable of precise temperature control to an accuracy of $\pm 0.2{ }^{\circ} \mathrm{C}$. For the other temperatures, we used a reliable freezer, refrigerators, and an incubator with an accuracy of $\pm 0.5^{\circ} \mathrm{C}$ as
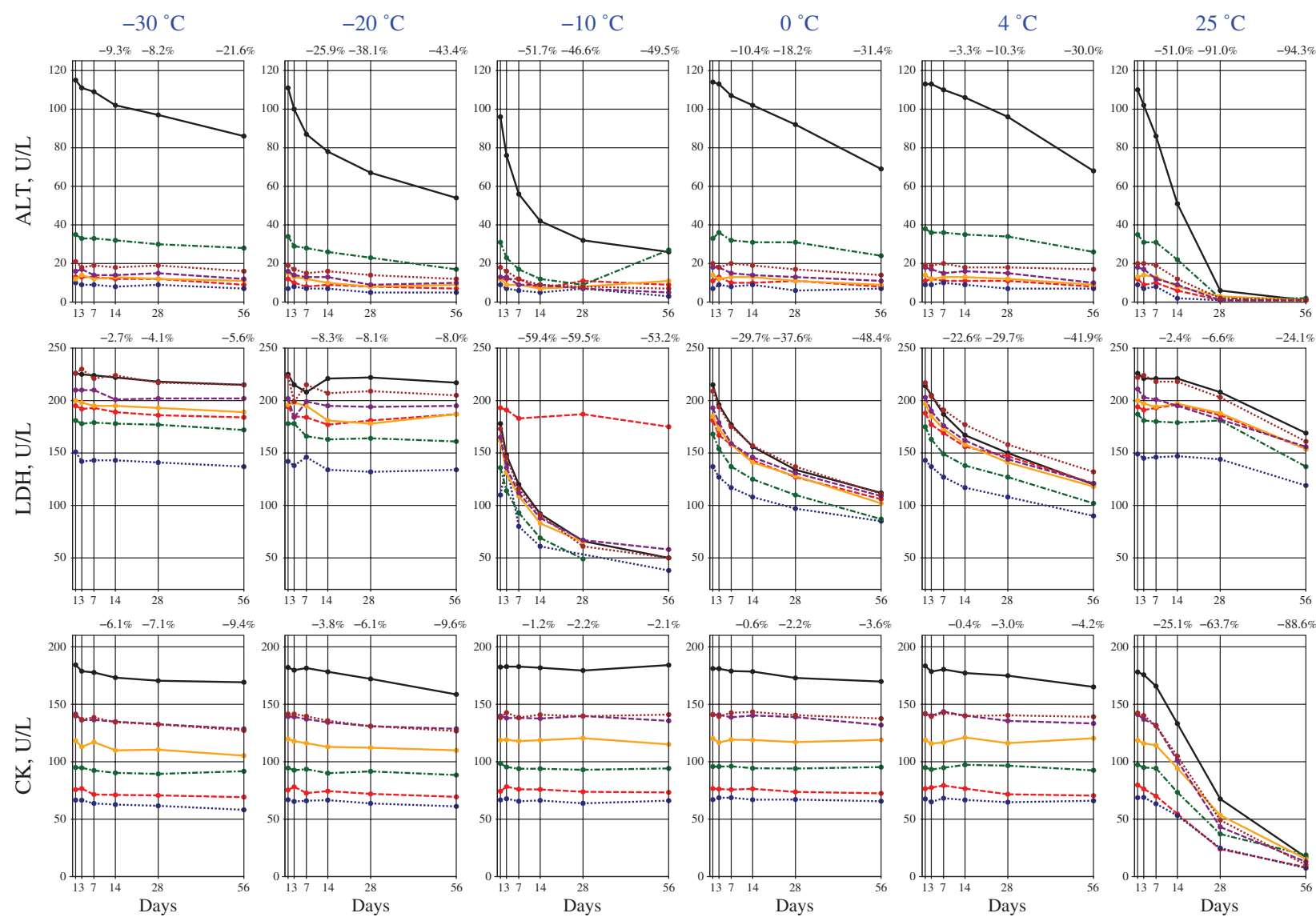

Figure 1: Change profiles of analytes over 2 months at six storage temperatures.

For six selected analytes, the time courses of test results for the seven sera are shown for each of the six storage temperatures. The data point for day 0 , which corresponds to the value of the specimen continuously stored at $-80^{\circ} \mathrm{C}$, is not shown. For days 14,28 and 56 , the average rates of change (\%) from day 0 are posted at the top of each graph. 

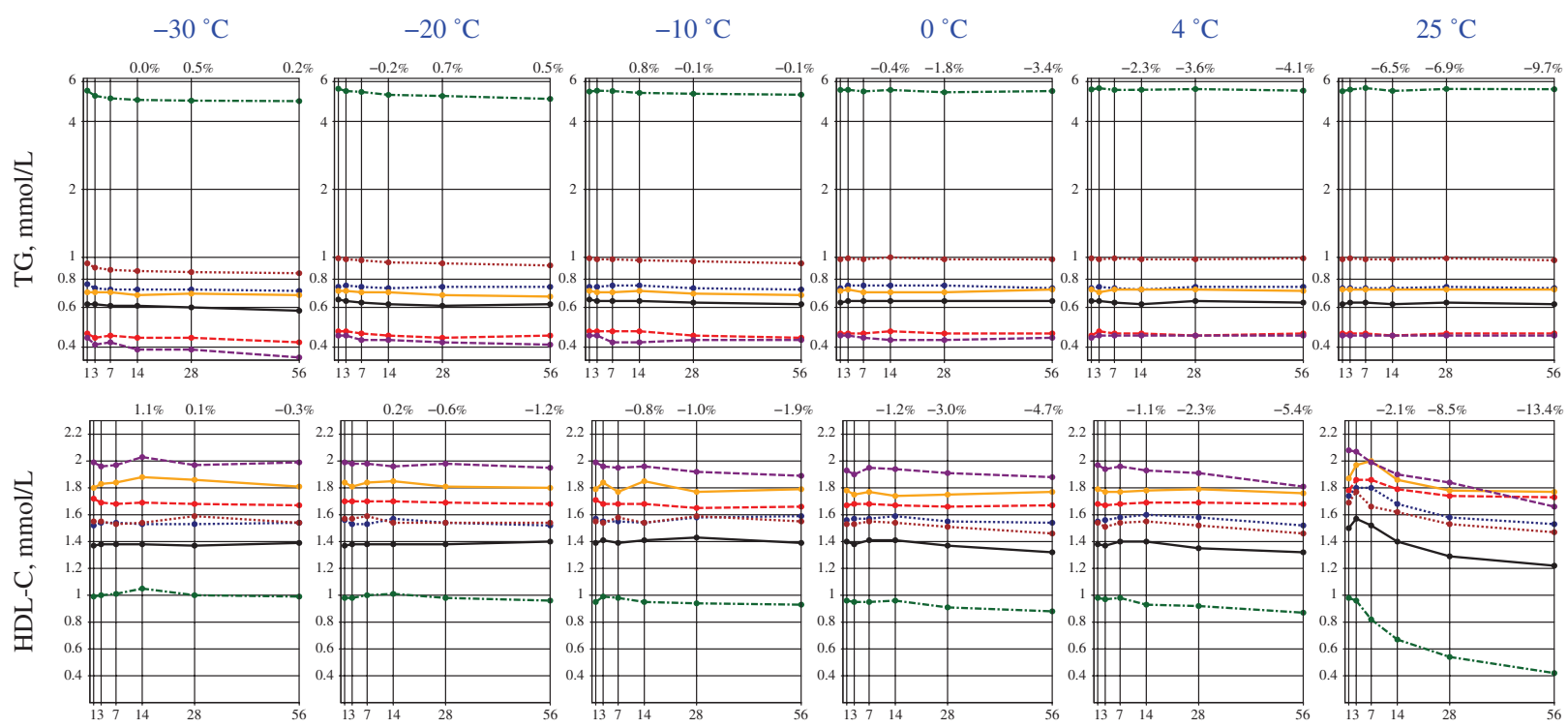

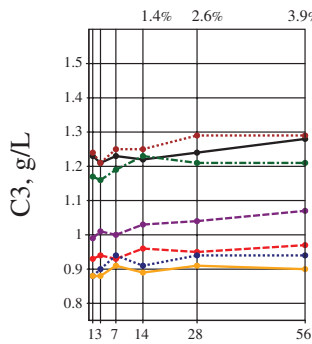

Days

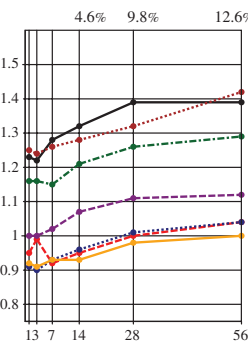

Days

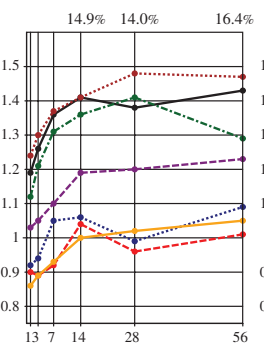

Days

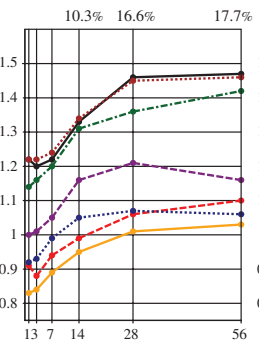

Days

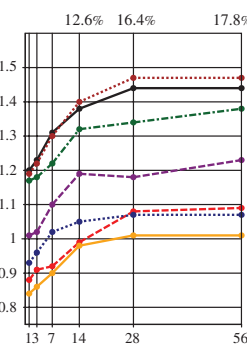

Days

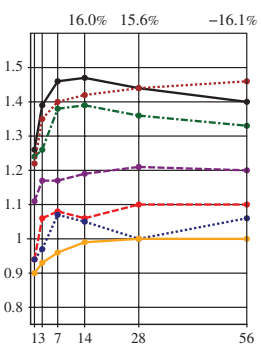

Days

Figure 1: (continued)

confirmed by digital thermometer. Therefore, we believe our results are reproducible despite the wide temperature range covered. We would emphasize that the evaluation of the specific storage temperatures of -10 and $0{ }^{\circ} \mathrm{C}$ with the use of reliable equipment for common biochemistry analytes was not done in the past.

Before discussing the implications of our study findings, we first need to assess the validity of our basic assumption that serum specimens are stable for all analytes if stored in a deep freezer (at $-80^{\circ} \mathrm{C}$ ), and therefore, test results of the specimens maintained at $-80^{\circ} \mathrm{C}$ can be regarded as basal values (values at day 0 ).

Ikeda et al. [1] analyzed the stability of 28 major biochemistry analytes in serum during 7 days of storage at $-80^{\circ} \mathrm{C},-20^{\circ} \mathrm{C}, 4^{\circ} \mathrm{C}$, and RT. All 13 of our analytes except $\mathrm{C} 3$ and $\mathrm{C} 4$ were included in their study, and all were shown to be stable at $-80{ }^{\circ} \mathrm{C}$ for 7 days. Zander et al. [2] also analyzed the stability of 32 biomarkers in serum and plasma at $4{ }^{\circ} \mathrm{C},-20^{\circ} \mathrm{C},-80^{\circ} \mathrm{C}$ and $-130^{\circ} \mathrm{C}$ for a duration of 90 days. Four of our analytes: ALT, LDH, CK, and C3, were included in their study and were shown to be stable at or below $-80{ }^{\circ} \mathrm{C}$ for 90 days by their criteria of significant fluctuation set as a change ratio of $>3$ times the betweenday analytical $\mathrm{CV}$ and $\mathrm{p}<0.01$.
More recently, Haslacher et al. [18] examined the storage stability of 26 biochemical analytes in serum at $-75^{\circ} \mathrm{C}$ for $14-21$ days and the effect of up to 30 repetitions of artificial fluctuations of temperature between -65 to $-75^{\circ} \mathrm{C}$. They observed no effect of temperature fluctuation at this narrow range but did show statistically significant changes in some of the analytes. All of our analytes except for LDL-C, C3, and C4 were included in their study. Only AMY was reported to show statistically significant decreases of $0.5 \%$ and $1.1 \%$ at days 14 and 21 , respectively, which we regard as practically insignificant compared with the allowable limit of error of $7.2 \%$ for AMY. No consistent changes were reported for our other analytes at $-75^{\circ} \mathrm{C}$ during storage for 21 days. Based on these assessments, we think it rational to assume the virtual stability of all of our analytes stored in the deep freezer at $-80{ }^{\circ} \mathrm{C}$ over the 60-day period or less.

\section{Comparison with findings of previous reports}

The lowering of serum LDH activity during storage at $4{ }^{\circ} \mathrm{C}$ and $-20^{\circ} \mathrm{C}$ is well known $[1,2,19]$. These changes were mainly attributed to the instability of isozymes LDH2-5, 


\begin{tabular}{|c|c|c|c|c|c|c|c|c|c|c|c|c|c|c|}
\hline Temp & Days & ALT & AST & ALP & LDH & GGT & A.MY & $\mathrm{CK}$ & TG & HDL-C & LDL-C & T-Bil & $\mathrm{C} 3$ & $\mathrm{C4}$ \\
\hline \multirow{5}{*}{$-30^{\circ} \mathrm{C}$} & 3 & -0.7 & -4.7 & 1.2 & -1.3 & -1.0 & -0.2 & -2.4 & 0.5 & -0.3 & -0.2 & 1.6 & -0.8 & -0.5 \\
\hline & 7 & -4.5 & 1.9 & -0.4 & -1.8 & -1.3 & 0.3 & -3.7 & 0.6 & -0.1 & -0.5 & 2.0 & 1.1 & -1.2 \\
\hline & 14 & -9.3 & $\mid-3.9$ & 0.5 & -2.7 & 0.4 & 0.4 & \begin{tabular}{|c|}
-6.1 \\
\end{tabular} & 0.0 & 1.1 & -0.2 & 2.4 & 1.4 & \begin{tabular}{|c|} 
\\
\end{tabular} \\
\hline & 28 & -8.2 & -3.6 & 0.1 & -4.1 & -1.2 & 0.1 & $\mid-7.1$ & 0.5 & 0.1 & 0.2 & 0.0 & 2.6 & $\mid-0.1$ \\
\hline & 56 & -21.6 & -3.4 & -0.2 & -5.6 & -0.6 & 0.2 & -9.4 & 0.2 & -0.3 & 0.0 & 0.4 & 3.9 & -0.8 \\
\hline \multirow{5}{*}{$-20^{\circ} \mathrm{C}$} & 3 & -12.6 & -3.4 & 1.2 & $\mid-6.4$ & $\mid-0.5$ & -0.4 & -1.2 & 1.1 & $\mid-0.4$ & 0.5 & 2.5 & 0.7 & 0.4 \\
\hline & 7 & -21.5 & -7.2 & 0.3 & -5.3 & -2.4 & 0.1 & -2.4 & 0.4 & 0.3 & 0.7 & 1.9 & 1.6 & 0.0 \\
\hline & 14 & -259 & -4.8 & -0.4 & $\mid-8.3$ & 0.7 & 0.0 & -3.8 & -0.2 & 0.2 & 1.3 & 2.3 & 4.6 & 1.0 \\
\hline & 28 & -38.1 & -6.8 & -2.3 & -8.1 & -1.0 & 0.0 & $\mid-6.1$ & 0.7 & -0.6 & 1.6 & 2.5 & 9.8 & 1.5 \\
\hline & 56 & -43.4 & -16.5 & -3.2 & -8.0 & -0.4 & 0.3 & -9.6 & 0.5 & -1.2 & 1.5 & -0.2 & 12.6 & 2.4 \\
\hline \multirow{5}{*}{$-10^{\circ} \mathrm{C}$} & 3 & -22.2 & -3.2 & 0.2 & -26.4 & -1.4 & $\mid-0.6$ & 0.1 & 1.0 & -0.1 & 0.0 & 2.5 & 1.9 & 4.5 \\
\hline & 7 & -35.8 & -5.7 & 0.0 & -41.3 & $\mid-3.0$ & -0.1 & -1.5 & 0.3 & -0.9 & -0.9 & 2.2 & 8.7 & 3.8 \\
\hline & 14 & -51.7 & -9.4 & -1.4 & $\mid-59.4$ & -1.5 & -0.4 & -1.2 & 0.8 & -0.8 & -1.6 & 2.5 & 149 & 4.6 \\
\hline & 28 & -46.6 & -13.3 & -2.4 & -59.5 & 0.1 & -0.1 & -2.2 & -0.1 & -1.0 & -1.9 & 0.8 & 14.0 & 3.4 \\
\hline & 56 & -49.5 & -24.3 & -6.3 & $\mid-53.2$ & 0.3 & 0.5 & $\mid-2.1$ & \begin{tabular}{|c|} 
\\
\end{tabular} & -1.9 & -3.6 & -2.7 & 16.4 & 4.2 \\
\hline \multirow{5}{*}{$0{ }^{\circ} \mathrm{C}$} & 3 & 0.1 & -3.5 & 0.1 & -14.4 & -1.3 & -0.9 & -0.5 & 0.2 & -2.0 & 0.2 & 2.6 & -1.8 & 1.8 \\
\hline & 7 & -9.3 & -2.9 & -0.7 & -22.1 & -1.6 & -0.8 & -0.3 & -0.1 & -1.2 & 0.6 & 1.9 & 2.4 & 3.9 \\
\hline & 14 & -10.4 & -4.7 & $\mid-0.6$ & $\mid-29.7$ & 0.0 & -1.4 & -0.6 & -0.4 & -1.2 & 1.1 & 1.3 & 10.3 & 5.7 \\
\hline & 28 & -18.2 & -15.8 & -0.8 & -37.6 & 0.7 & -0.5 & -2.2 & -1.8 & -3.0 & 1.2 & -2.0 & 16.6 & 5.0 \\
\hline & 56 & -31.4 & -25.0 & -1.1 & -48.4 & -1.7 & -0.4 & -3.6 & -3.4 & -4.7 & -0.8 & -6.6 & 17.7 & 4.1 \\
\hline \multirow{5}{*}{$4^{\circ} \mathrm{C}$} & 3 & -2.8 & -4.2 & 0.3 & $\mid-9.2$ & -0.6 & $\mid-0.9$ & -1.8 & 0.8 & -1.7 & 0.2 & 2.3 & 0.2 & 1.1 \\
\hline & 7 & -2.3 & -7.4 & -0.5 & -15.6 & 0.4 & -1.2 & 0.4 & $\mid-0.8$ & $\mid-0.6$ & 1.5 & 1.8 & 5.2 & 2.2 \\
\hline & 14 & -3.3 & -8.5 & -0.7 & -22.6 & 1.9 & -0.2 & -0.4 & -2.3 & -1.1 & 2.0 & 0.8 & 12.6 & 4.7 \\
\hline & 28 & -10.3 & $\mid-15.3$ & -0.1 & -29.7 & -0.2 & $\mid-0.2$ & -3.0 & \begin{tabular}{|l|}
-3.6 \\
\end{tabular} & -2.3 & 2.2 & -2.4 & 16.4 & 5.8 \\
\hline & 56 & -30.0 & -25.9 & -1.1 & -41.9 & 1.3 & -0.4 & -4.2 & -4.1 & -5.4 & 1.6 & -9.9 & 17.8 & 6.0 \\
\hline \multirow{5}{*}{$25^{\circ} \mathrm{C}$} & 3 & -9.0 & -8.1 & 2.5 & -2.0 & -0.6 & -0.6 & -1.4 & -4.1 & 9.0 & 0.5 & -27.0 & 10.2 & 5.1 \\
\hline & 7 & -14.7 & -18.5 & 2.1 & -2.5 & 0.3 & -1.3 & -6.2 & -4.5 & 4.9 & -2.4 & -42.2 & 15.5 & 8.4 \\
\hline & 14 & -51.0 & \begin{tabular}{|l|}
-33.6 \\
\end{tabular} & 3.9 & -2.4 & 1.1 & $\mid-1.7$ & $\mid-25.1$ & $\mid-6.5$ & -2.1 & $\mid-10.1$ & -82.2 & \begin{tabular}{|l|}
16.0 \\
\end{tabular} & 10.9 \\
\hline & 28 & -91.0 & $\mid-65.0$ & 0.4 & -6.6 & -4.1 & -1.2 & -63.7 & -6.9 & -8.5 & -17.9 & -86.4 & 15.6 & 9.0 \\
\hline & 56 & -94.3 & -94.9 & -10.3 & -24.1 & -8.8 & -1.6 & -88.6 & $\mid-9.7$ & -13.4 & -18.7 & -87.4 & 16.1 & 10.0 \\
\hline \multicolumn{2}{|c|}{$\mathrm{ALE}$} & 11.48 & 6.54 & 6.72 & 4.26 & 11.06 & 7.40 & 11.51 & 9.57 & 5.61 & 5.46 & 8.95 & 4.11 & 8.64 \\
\hline
\end{tabular}

Figure 2: Effects of specimen storage period and temperature on laboratory test results.

Values and lengths of color bars listed for day 3 to day 56 are averages of change ratios (\%) compared to the base value (test result of the specimen stored at $-80^{\circ} \mathrm{C}$ for 60 days). Statistical signficance of the change from the base value: $p<0.05=$ bold font; $p<0.01=$ light gray background; $p<0.001$ = gray background. The allowable limit of error (ALE) that was calculated as $0.5 \times \mathrm{CV}_{1}$ (within-individual CV) for each analyte is shown in the bottom row. The values of change ratios exceeding the ALE are marked in blue font.

especially LDH4-5, whereas LDH1 is relatively stable at these temperatures [19].

We found LDH activity to be fairly stable at $25^{\circ} \mathrm{C}$ and $-30{ }^{\circ} \mathrm{C}$ at least for the first 14 days. Our finding for the former temperature is consistent with past reports [1, 19]. In contrast, LDH activity was very unstable at temperatures between $-20{ }^{\circ} \mathrm{C}$ and $4{ }^{\circ} \mathrm{C}$ and was least stable at $-10{ }^{\circ} \mathrm{C}$ followed by $0{ }^{\circ} \mathrm{C}, 4{ }^{\circ} \mathrm{C}$ and $-20{ }^{\circ} \mathrm{C}$. This finding at $0^{\circ} \mathrm{C}$ is new. In summary, for long-term storage of serum for LDH ( $\geq 1$ month), it would be best to store serum specimens in a deep freezer. Storage at temperatures between $-10{ }^{\circ} \mathrm{C}$ to $4^{\circ} \mathrm{C}$, even for a short time, should be avoided, whereas storage at $25^{\circ} \mathrm{C}$ seems to cause no problems up to 14 days.

Serum ALT activity after storage for a few days or more is well known to be unstable both at RT $\left(22-25^{\circ} \mathrm{C}\right)[1,4]$ and $-20{ }^{\circ} \mathrm{C}[1,2,4]$ but is relatively stable at $4{ }^{\circ} \mathrm{C}[4,11$, 15]. However, the relative magnitude of instability across various temperature conditions has not been clarified. Our results clearly showed that storage temperatures between $-20{ }^{\circ} \mathrm{C}$ and $-10{ }^{\circ} \mathrm{C}$ were the least recommended for ALT even for a period of 3 days. Progressive instability after 7-14 days was also noted for temperatures at $-30{ }^{\circ} \mathrm{C}$, $0{ }^{\circ} \mathrm{C}$ and $25^{\circ} \mathrm{C}$. In contrast, ALT remained relatively stable at $4^{\circ} \mathrm{C}$ for up to 14 days. Meanwhile, we confirmed the stability of ALT activities at $-80^{\circ} \mathrm{C}$ as we did for the other 12 analytes (data not shown). In summary, serum specimens for ALT testing can be kept at $4{ }^{\circ} \mathrm{C}$ for up to 14 days and are best stored in a deep freezer for any longer period. Storage at -20 to $-10{ }^{\circ} \mathrm{C}$ does not appear to be appropriate even for a few days.

Our findings for the pattern of instability for AST were similar to those of ALT but were much less prominent except at $25^{\circ} \mathrm{C}$. In addition to the reports of the stability of AST activity at $4^{\circ} \mathrm{C}[1]$, one report found a $51.3 \%$ reduction 
in plasma within 3 days [20]. However, our results at 4 ${ }^{\circ} \mathrm{C}$ showed much smaller reductions of only $4 \%$ at day 3 and $8.5 \%$ at day 14 . It is notable that this reduction at 4 ${ }^{\circ} \mathrm{C}$ is relatively stronger than that of ALT. In conclusion, serum for AST needs to be stored at $-30{ }^{\circ} \mathrm{C}$ or below. No other storage temperature appears to be appropriate even though the magnitude of the changes is relatively small compared with that of ALT.

For CK, there are multiple reports of either a slight [2] or prominent [3] lowering of its activity at $-20^{\circ} \mathrm{C}$. At 25 or $20^{\circ} \mathrm{C}$, there are multiple reports of decreased activity [1, $3]$, and at $4{ }^{\circ} \mathrm{C}$, the reports are mixed, showing either no change $[21,22]$ or a decrease $[1,3]$. The decreased activity at -20 and $4{ }^{\circ} \mathrm{C}$ was attributed to all three isozymes of CK [3]. In contrast, Friedman et al. reported no changes in the isozyme profile at -20 and $4{ }^{\circ} \mathrm{C}$ after 3 months of storage [22]. From our study, we noted only a slight decrease in activity at $-20{ }^{\circ} \mathrm{C}: 3.8 \%$ on day 14 and $6.1 \%$ on day 28. A similar decrease was also noted at $-30{ }^{\circ} \mathrm{C}$. In contrast, $\mathrm{CK}$ activity was very stable at storage temperatures between -10 and $4{ }^{\circ} \mathrm{C}$ compared to storage at -30 or $-20^{\circ} \mathrm{C}$. It is difficult to explain this paradoxical reversal of the freezing effect, unlike that in the other enzymes, but we assume that restricted mobility of CK molecules under a deeper freezing condition is harmful to its structure and thus causes the decrease in activity. However, at $25{ }^{\circ} \mathrm{C}$, CK activities decreased progressively after day 7. In conclusion, specimens for testing of CK can be stored at $-10,0$, or $4^{\circ} \mathrm{C}$ for up to 14 days, but storage at $-30,-20$, and $25^{\circ} \mathrm{C}$ for more than 7 days should be avoided.

For ALP, all of the recent reports showed the stability of ALP activity at RT $\left(25\right.$ or $\left.20^{\circ} \mathrm{C}\right), 4^{\circ} \mathrm{C}[1,2,15]$ and $-20^{\circ}$ [1]. The present study essentially confirmed the findings for these temperatures and also showed its stability at $-30{ }^{\circ} \mathrm{C},-10^{\circ} \mathrm{C}$ and $0{ }^{\circ} \mathrm{C}$. Therefore, serum for retesting ALP can be stored over the full range of temperatures at least for 1 month.

The high stability of GGT and AMY even after long storage at RT and at 4 and $-20^{\circ} \mathrm{C}$ is well known $[1,5,11$, 14]. We confirmed their stability over the full range of temperatures for at least 1 month, as noted above for ALP.

We noted a prominent decrease in TBil at $25^{\circ} \mathrm{C}$ within a few days, but there were no noticeable changes in serum TBil at the other temperatures except for a minor decrease observed when specimens were left at $0^{\circ} \mathrm{C}$ or $4^{\circ} \mathrm{C}$ for more than 28 days. In interpreting these results, it is important to note that we took special care to avoid the well-known degradation of the molecule by ultraviolet rays during storage. Therefore, the findings we obtained appeared to be primarily attributable to temperature-dependent molecular change. In our literature search, we noted one report of a similar decrease in TBil at $25^{\circ} \mathrm{C}$ even within a few days [1]. However, at $4^{\circ} \mathrm{C}$, there is a report of a reduction within hours [20] unlike our finding of the stability of TBil until day 28.

For C3, its peculiar pattern of a gradual increase with storage has been well documented at $18-22{ }^{\circ} \mathrm{C}$ and at 4 and $-20{ }^{\circ} \mathrm{C}[2,23]$. This has been attributed to its degradation into $\mathrm{C} 3 \mathrm{~b}$ and $\mathrm{C} 3 \mathrm{c}$ during storage [23]. We showed a similar increase even at temperatures between -10 and $0{ }^{\circ} \mathrm{C}$. The same tendency was also observed for $\mathrm{C} 4$, but the trend was much less pronounced. In the literature, serum C4 was reported to both increase [24] or decrease [23] at $4^{\circ} \mathrm{C}$. We assume that the discrepancy is attributed to differences in antibody specificities against the degradation products.

There have been numerous reports on the stability of the lipids TG, HDL-C and LDL-C because of the strong clinical demand for laboratory testing of these analytes. Most studies examined stability at -20 or $4{ }^{\circ} \mathrm{C}$, and their results are mixed [9, 25-28]. Pini et al. [29] showed increases of HDL-C and LDL-C by $4 \%$ and $7 \%$, respectively, after 7 days of storage both at -20 and $4{ }^{\circ} \mathrm{C}$, whereas Tiedink and Katan [30] reported a decrease of both LDL-C and HDL-C by $<4.1 \%$ after 11 weeks of storage at $-20{ }^{\circ} \mathrm{C}$. Furthermore, Bausserman et al. [31] found no changes at $-20{ }^{\circ} \mathrm{C}$ for up to 1 month or at 30 days. We found all three lipids to be very stable at any temperature below $4{ }^{\circ} \mathrm{C}$ for 4 weeks. At $25^{\circ} \mathrm{C}$, however, test results for TG decreased by $4 \%$ on day 3 and by $7 \%$ on day 28 , and those for HDL-C showed a biphasic pattern with an increase of $9 \%$ on day 3 but a decrease of $8.5 \%$ on day 28 . Regarding the increase in HDL-C, Pini et al. reported that if the specimens are left at RT, LCAT (lecithin:cholesterol acyltransferase) in serum acts on HDL to transiently increase the cholesterol content [29]. We conclude that all three lipids are stable for at least 2 months if stored at or below $-10^{\circ} \mathrm{C}$. However, storage of serum at RT even for a few days does not appear to be appropriate because of the pseudo-increase in HDL-C.

\section{Limitations}

One limitation of this study is that we examined the storage stability of major biochemical analytes from only seven healthy volunteers. Although we observed the overall consistency of the time-serial change patterns among the individuals, each checked for statistical significance, we need to be cautious in generalizing our results because we may have missed a peculiar profile of changes in some 
individuals, the elucidation of which requires the analysis of a larger number of individuals. Furthermore, we only covered test results of healthy individuals and therefore cannot deny the possibility that test results of the analytes at higher than normal levels may show a different profile of changes.

The other limitation is that the evaluation of the effects of storage at a temperature of $25^{\circ} \mathrm{C}$ for a period of 7 days or longer has no practical meaning due to the feasibility of microbial contamination of the specimens. However, we did not note any visible changes in the appearance of the specimens during the study period because all specimen containers were tightly sealed.

\section{Conclusions}

This is the first comprehensive study to elucidate storage stability profiles of serum specimens of common biochemistry analytes over six graded temperatures: -30 , $-20,-10,0,4$ and $25^{\circ} \mathrm{C}$. Serum specimens freshly sampled from seven healthy volunteers were divided into multiple aliquots and stored in chambers accurately controlled at all six temperatures. Then, after 1, 3, 7, 14, 28 and 56 days, aliquots designated for a given storage time and temperature were relocated one by one to a deep freezer (at $-80^{\circ} \mathrm{C}$ ). To eliminate any influence of between-day assay variations, all measurements were then collectively performed on day 60 .

Serum ALT activity was reduced by storage at all temperature ranges, especially at $-20,-10$, and $25{ }^{\circ} \mathrm{C}$. AST activity showed a similar but much less prominent pattern of reduction. $\mathrm{LDH}$ activity was unstable at $-10,0$, and $4{ }^{\circ} \mathrm{C}$ in that order of magnitude. CK activity was peculiar in that it was rather stable at temperatures between -10 and $4{ }^{\circ} \mathrm{C}$ but decreased when stored at -20 or $25^{\circ} \mathrm{C}$ for 2 weeks or more. Other enzymes, GGT, AMY and ALP, were very stable over the entire temperature range. TG, HDL-C and LDL-C were very stable when stored below $4{ }^{\circ} \mathrm{C}$, but some fluctuations were noted at $25^{\circ} \mathrm{C}$. TBil was very stable if stored at $4{ }^{\circ} \mathrm{C}$ or below, but a prominent decrease in test results was noted at $25^{\circ} \mathrm{C}$. In contrast, $\mathrm{C} 3$ and $\mathrm{C} 4$ showed storagedependent increases in their values for any temperature above $-20^{\circ} \mathrm{C}$.

We could elucidate a clearer picture of storagedependent changes in the test results across a wide range of storage temperatures for 13 major laboratory tests. These results should be useful for clinical laboratories in determining optimal conditions for storing serum specimens of each analyte for future retesting.
Author contributions: YS and KI designed the research. YS conducted the experiment and measured all of the specimens under the guidance of KI. YS and KI performed data analyses. KI and YS wrote the manuscript. All the authors have accepted responsibility for the entire content of this submitted manuscript and approved submission.

Research funding: A research fund provided by the Japan Society for Promotion of Science (JSPS) (Kaken-hi No. 25460688: 2013-2016) was used for this study.

Employment or leadership: None declared.

Honorarium: None declared.

Competing interests: The funding organization(s) played no role in the study design; in the collection, analysis, and interpretation of data; in the writing of the report; or in the decision to submit the report for publication.

\section{References}

1. Ikeda K, Ichihara K, Hashiguchi T, Hidaka Y, Kang D, Maekawa M, et al. Evaluation of the short-term stability of specimens for clinical laboratory testing. Biopreserv Biobank 2015;13:135-43.

2. Zander J, Bruegel M, Kleinhempel A, Becker S, Petros S, Kortz $\mathrm{L}$, et al. Effect of biobanking conditions on short-term stability of biomarkers in human serum and plasma. Clin Chem Lab Med 2014;52:629-39.

3. Nealon DA, Henderson AR. Stability of commonly used thiols and of human creatine-kinase isoenzymes during storage at various temperatures in various medias. Clin Chem 1977;23:816-29.

4. Williams KM, Williams AE, Kline LM, Dodd RY. Stability of serum alanine aminotransferase activity. Transfusion 1987;27:431-3.

5. Jansen E, Beekhof P, Viezeliene D, Muzakova V, Skalicky J. Longterm stability of cancer biomarkers in human serum: biomarkers of oxidative stress and redox status, homocysteine, CRP and the enzymes ALT and GGT. Biomarkers 2015;9:425-32.

6. Devanapalli B, Bermingham MA, Mahajan D. Effect of long-term storage at -80 degrees $C$ on the various lipid parameters in stored plasma samples. Clin Chim Acta 2002;322:179-81.

7. Ekbom T, Lindholm LH, Lanke J, Nilsson-Ehle P. Decrease in high density lipoprotein cholesterol during prolonged storage. CELL Study Group. Scand J Clin Lab Invest 1996;56:97-101.

8. Nanjee MN, Miller NE. Evaluation of long-term frozen storage of plasma for measurement of high-density lipoprotein and its subfractions by precipitation. Clin Chem 1990;36:783-8.

9. Kuchmak M, Taylor L, Olansky AS. Suitability of frozen and lyophilized reference sera for cholesterol and triglyceride determinations. Clin Chim Acta 1982;120:261-71.

10. Gislefoss RE, Grimsrud TK, Mørkrid L. Stability of selected serum hormones and lipids after long-term storage in the Janus Serum Bank. Clin Chem 2015;48:364-69.

11. Mijovic V, Contreras M, Barbara J. Serum alanine aminotransferase (ALT) and $\gamma$-glutamyltransferase $(\gamma$-GT) activities in north London blood donors. J Clin Pathol 1987;40:1340-4.

12. García S, Fernández A, Luengo J, Herrera F. Advanced nonparametric tests for multiple comparisons in the design of experiments in computational intelligence and data 
mining: experimental analysis of power. Inform Sciences 2010;180:2044-64.

13. Kachhawa K, Kachhawa P, Varma M, Behera R, Agrawal D, Kumar S. Study of the stability of various biochemical analytes in samples stored at different predefined storage conditions at an accredited laboratory of India. J Lab Physicians 2017;9:11-5.

14. Nielsen BK, Frederiksen T, Friis-Hansen L, Larsen PB. Postanalytical stability of 23 common chemistry and immunochemistry analytes in incurred samples. Clin Biochem 2017;50:1175-82.

15. Chua C, Tifigiu E, Momeni A, Laskar D, Shafique K, Zuretti A, et al. Stability of values for the activities of critical enzymes assayed in serum. Clin Diagn Pathol 2017;3:1-4.

16. Donnelly JG, Soldin SJ, Nealon DA, Hicks JM. Stability of twentyfive analytes in human serum at 22 degrees C, 4 degrees $C$, and -20 degrees C. Pediat Path Lab Med 1995;15:869-74.

17. Wilson SS, Guillan RA, Hocker EV. Studies of the stability of 18 chemical constituents of human serum. Clin Chem 1972;18:1498-503.

18. Haslacher H, Szekeres T, Gerner M, Ponweiser E, Repl M, Wagner $\mathrm{OF}$, et al. The effect of storage temperature fluctuations on the stability of biochemical analytes in blood serum. Clin Chem Lab Med 2017;55:974-83.

19. Jacobs E, Hissin PJ, Propper W, Mayer L, Sarkozi L. Stability of lactate dehydrogenase at different storage temperatures. Clin Biochem 1986;19:183-8.

20. Van Vrancken MJ, Briscoe D, Anderson KM, Wians Jr. FH. Timedependent stability of 22 analytes in lithium-plasma specimens stored at refrigerator temperature for up to 4 days. Lab Med 2012;43:268-75.

21. Shain SA, Boesel RW, Klipper RW, Lancaster CM. Creatine kinase and lactate dehydrogenase: stability of isoenzymes and their activity in stored human plasma and prostatic tissue extracts and effect of sample dilution. Clin Chem 1983;29:832-5.

22. Friedman DL, Kesterson R, Puleo P, Wu AH, Perryman MB. Recombinant creatine kinase proteins and proposed standards for creatine kinase isoenzyme and subform assays. Clin Chem 1993;39:1598-601.

23. Sinosich MJ, Teisner B, Brandslund I, Fisher M, Grudzinskas JG. Influence of time, temperature and coagulation on the measurement of C3, C3 split products and C4. J Immunol Methods 1982;55:107-14.

24. Maguire OC, Curry MP, O'Gorman P, Parfrey N, Hegarty J, Cunningham SK. In vitro cold activation of complement shown by an overestimation of total complement 4: a study in patients with hepatitis $\mathrm{C}$ virus infection. Ann Clin Biochem 2001;38:687-93.

25. Evans K, Mitcheson J, Laker MF. Effect of storage at 4 degrees $\mathrm{C}$ and -20 degrees $\mathrm{C}$ on lipid, lipoprotein, and apolipoprotein concentrations. Clin Chem 1995;41:392-6.

26. Bachorik PS, Walker R, Brownell KD, Stunkard AJ, Kwiterovich $P O$. Determination of high density lipoprotein-cholesterol in stored human plasma. J Lipid Res 1980;21:608-16.

27. Holzer M, Kern S, Trieb M, Trakaki A, Marsche G. HDL structure and function is profoundly affected when stored frozen in the absence of cryoprotectants. J Lipid Res 2017;58: 2220-8.

28. Zivkovic AM, Wiest MM, Nguyen UT, Davis R, Watkins SM, German JB. Effects of sample handling and storage on quantitative lipid analysis in human serum. Metabolomics 2009;5:507-16.

29. Pini C, Sommariva D, Branchi A, Scandiani L, Fasoli A. Effects of serum storage on the determination of cholesterol. Res Clin Lab 1990;20:37-44.

30. Tiedink HG, Katan MB. Variability in lipoprotein concentrations in serum after prolonged storage at -20 degrees $C$. Clin Chim Acta 1989;180:147-55.

31. Bausserman LL, Saritelli AL, Milosavljevic D. High-density lipoprotein subfractions measured in stored serum. Clin Chem 1994;40:1713-6.

Supplementary Material: The online version of this article offers supplementary material (https://doi.org/10.1515/cclm-2018-1109). 